\title{
Framing alleged Islamist plots: a case study of British press coverage since 9/11
}

\begin{abstract}
In the decade post 9/11, the UK terrorist threat was associated with a series of high-profile counter-terrorism operations, linked to specific plots. These terrorismrelated episodes received significant media attention and, as a consequence, were a visible sign of the contemporary terrorist threat. This paper seeks to identify the dominant frames rendered in news media reporting on these episodes. Through a longitudinal study of UK press coverage, the analysis reveals that two prominent frames were present, an inevitability and preparedness frame, with alleged plots serving to underline the risk posed by contemporary terrorism, and a belonging and responsibility frame, which cast later episodes as belonging to the Muslim communities disrupted by police operations.
\end{abstract}

\section{Keywords: terrorism; alleged plots; news framing; newspapers}

In the wake of September 11 the UK government often made claims about the number of active terrorist plots that the security services were tracking (Miller and Sabir, 2012, 88). Foiled plots thus became significant indictors of the terrorist threat to the UK, with media reporting on counter-terrorism interventions by the police and security services sharing the characteristics of coverage actual or failed incidences of political violence, typified by rolling updates across broadcast news outlets and speculation concerning the nature of specific threats. This paper argues, therefore, that media representations of these significant terrorism-related episodes, in part, shaped public understanding of contemporary terrorist threat.

While there are numerous studies of media coverage of 'new terrorism' (Spencer, 2010) and significant events such as 9/11 (Eisman, 2003; Norris, Montague and Just, 2003; Xigen and Izard, 2003; Zelizer and Allan, 2002), the Madrid (Burkitt, 2005) and London bombings (Brinson and Stohl, 2009), there has been very little attention paid to alleged plots, as significant terrorismrelated episodes. This article seeks to address this gap, examining media coverage of foiled Islamist plots to identify the dominant frames rendered in news narratives to these terrorism-related episodes. It also considers how frames evolved across the period of analysis and the extent to which media representations of these episodes reflected broader discourses on contemporary terrorism.

\section{Alleged plots and contemporary terrorism}

This article focuses on news reporting on a series of alleged terrorist plots. Following a longitudinal approach, with the study starting on September 11 2001 and running up until the tenth anniversary of these events in 2011, media representations of six alleged plots are considered as a single body of discourse. The first episode included in the study is an alleged ricin plot from January 2003, 
where press reports claimed that police had uncovered ricin poison at a flat in Wood Green, North London. The second event emerged in April 2004, where it was alleged that police had foiled a plot to target Old Trafford, the home of Manchester United Football Club, with liquid explosives. Two further episodes received significant news coverage in 2006 and are also included in the study: a counter-terrorism operation on June 2, 2006 in Forest Gate, East London, linked to a chemical bomb plot, and a series of arrests on August 10, 2006 that media reports claimed had thwarted a plot to down transatlantic airliners. The fifth episode concerned allegations that nine people arrested on January 31, 2007 had planned to kidnap and behead a Muslim solider serving in the British army. The final episode included in the study was a series of counter-terrorism raids on April 9, 2009 connected to an alleged plot to target public spaces in the northwest of England.

These episodes reflect a series of events in the decade post 9/11 that can be described as 'terrorism-related' but were constituents of a broader framework of contemporary terrorism. Each received considerable media attention, often sharing the characteristics of reporting on acts of violence, with live television broadcasts from the scene and a shifting, and frequently conflicting, narrative to events (Graber, 1997; Perse, 2001). Significantly, initial news coverage of these episodes was highly speculative, and in addition to information about the counter-terrorism operation and matters of criminal process, reports provided detailed and sometimes lurid descriptions about how the plots would have played out (and their potential impact) without intervention by the police and security services. Subsequent criminal proceedings, however, have only substantiated two of the six episodes analysed in this study as credible threats, resulting in convictions under terrorism statutes.

Each of these episodes, this paper argues, served to remind the British public that terrorism was a latent and perpetual risk. Indeed, some have suggested that these episodes were deliberately misrepresented by senior security officials providing information to journalists through off-the-record meetings (Miller \& Sabir, 2012). Following reports of a foiled kidnap plot in January 2007, for instance, subsequent analysis and comment indicated that some journalists were informed in advance of police raids and then kept updated about the allegations through a series of secret briefings (Cobain, Dodd, and Woodward, 2007). At the time, these revelations fed into wider debates concerning the veracity of government communications and also led support to the view that the British government, particularly under Tony Blair's premiership, sought to overstate the risk of violence from Islamist or Jihadist groups to promote public insecurity and legitimise a range of foreign and domestic policy responses that the UK government deemed necessary to maintain security and fight terrorism. Policies that, in reality, as others have argued, were disproportionate to the threat posed by such actors, and only 
served to heighten public anxiety and concern over terrorism (Jackson, 2005; Lewis, 2012).

This paper documents media representations of these breaking news events, employing qualitative textual analysis to identify dominant news frames and their characteristics. Since frames are important in communicating aspects of perceived reality their use by journalists to report significant terrorismrelated episodes can also contribute to public understanding of the causes and appropriate policy responses to terrorism (Entman, 1993). This study, therefore, considers how news frames rendered in UK media coverage of alleged plots reflected broader socio-political discourse on contemporary terrorism.

\section{Theoretical framework: Media and terrorism and news framing}

Much of the early work analysing the relationship between the media and terrorism subscribed to the orthodoxy: that terrorists seek publicity for their cause through acts of violence (Crenshaw, 1981; Wilkinson, 1997).

The potential for terrorists to reach receptive and supportive audiences, to harness support, and increase legitimacy through international coverage of their cause, demonstrates for some, the media's capacity to amplify the terrorist threat. Midlarsky, Crenshaw and Yoshida (1980) argued that mass media coverage of terrorism can lead to a contagion effect, witnessing 'successful' attacks on television will allow terrorists to copy the tactics of other groups and motivate them to employ similar campaigns of violence. This type of thinking dominated conservative strategic studies and led to self-regulation by the media, or government imposed controls upon the coverage of terrorism and access to terrorist organisations and their political affiliates (Carruthers, 2000, 190).

The publicity thesis assumes that the influence of media coverage on audiences is uniform. Therefore, it portrays audiences as a 'monolithic and homogenous entity' (Archetti, 2013, 50), subscribing to a simplistic interpretation of a largely discredited model of direct media effects (Picard, 1991), failing to acknowledge how audiences decode and construct meaning from the same text (Hall, 1973).

The present study aligns with a constructionist approach (Pan and Kosicki, 1993), where the media help to structure discourse on terrorism by drawing attention to certain aspects of perceived reality, with media representations of alleged plots intertwining with public experience and understanding of contemporary terrorism.

Theories of news framing are indelibly linked to the media's role in constructing social reality. Frames act as interpretative packages which provide a central organising idea that connect a series of unfolding news events or are employed by journalists to help their audiences make sense of complex issues (Gamson and Modigliani, 1989). The process of framing can thus occur across all stages of the news cycle as journalists prioritise particular subjective elements in the selection, presentation and interpretation of news, thereby drawing 
audiences' attention to particular aspects of issues and events. News frames, as a consequence, can shape how a problem is defined, its causes and potential solutions (Entman, 1993), or construct an event or issue in such a way that it favours a particular side or policy response (Tankard, 2001).

Frame analysis has been used as an empirical tool to explore audience perception, evaluation and response to different interpretations of issues or events, with frames acting as an independent variable to explore causal processes (Scheufele, 1999, 107). It does sit more comfortably, however, within a constructionist perspective, with frames emerging from the interaction between audience and news discourse (Pan and Kosicki, 1993; Van Gorp, 2007). The present study aligns with this broader approach, where framing may be viewed as a multidirectional process, with news frames shaped by culture and society. Frames, therefore, as Entman $(1993,52)$ describes can be found in four locations: 'the communicator, the text, the receiver and the culture.' So the structures of meaning that journalists draw on when presenting news may reflect culture as much as individual schemata or 'persistent patterns of cognition and interpretation' (Gitlin, 1980, 7).

In the same vein, Van Gorp (2007), describes frames as 'packages' employed by a range of actors, not only the news media but other groups within society, which may be used to describe one issue or event but are often employed to describe others. It is important, therefore, that news frames are not analysed in isolation but recognise the dominant discourses that are reproduced in news texts.

A methodological distinction can be drawn between those studies of news framing which have sought to identify generic frames, found across news coverage of a range of topics, and those that pertain to a particular issue or event (de Vreese, 2005). Generic frames stem from the professional practices of journalism, news values and the tendency for journalists to turn to official sources for example, which dictate story selection and how topics are presented to news audiences. Significantly, this approach assumes that such frames can be applied to almost all topics and events that are reported in the news. Iyengar and Kinder (1987), for example, examined frames that can be found across different issues, describing frames as either thematic or episodic in nature. Thematic news frames, they argue, present issues in terms of 'societal or collective' outcomes, emphasising information that highlights particular trends or policy to contextualise a story, where episodic frames use concrete examples, often through personal experience provided by individuals, to describe issues or events. The consequence of such episodic frames elements is that it tends to ascribe responsibility for an issue to individuals, rather than societal factors. So reporting on foiled plots that emphasised the dramatic nature of police intervention and the reaction of communities disrupted by counter-terrorism actions, may lack the contextual information that is important for audiences to help make sense of terrorism. 
In contrast with generic frames, issue-specific frames centre on the recurrent thematic patterns relevant to coverage of a specific issue or news event (de Vreese, 2005). Such studies provide a detailed exposition of news coverage, but richness and depth are also tempered by a lack of generalizability, producing findings which may be simply descriptive and fail to extend theory (Tankard, 2001, 104).

Consequently, the approach emphasised in the present study was to identify the topical characteristics of frames rendered in news coverage of alleged plots, but also to recognise how issue-specific frames were informed by or demonstrate the presence of broader frameworks of meaning, which serve as organising principles to connect and provide context to related events (Gamson and Modigliani, 1989; Reese and Lewis, 2009).

There is a sizeable body of literature examining media coverage of terrorism, in particular the representation and framing of terrorist attacks (See Brinson and Stohl, 2009; Papacharissi and Oliveira, 2008) the War on Terror (See Eisman, 2003; Glazier and Boydstun, 2012; Norris, Kern and Just, 2003; Reese and Lewis, 2009), and news discourse on terrorism and counter-terrorism (See Awan, Hoskins, and O'Loughlin, 2011; Spencer, 2010). This section will therefore review studies of media portrayals and discourse on terrorism, with a particular focus on terrorism frames in the US and UK media.

Norris, Kern and Just (2003) argue that following 9/11 the US media and government adopted a 'War on Terrorism' frame, which allowed politicians and journalists alike to place global news events, particularly within the realm of conflict, into an overall narrative. US news coverage of terrorism therefore became thematic, providing context by attempting to place events within a broader interpretative framework (Powell, 2011). Norris et al. (2003, 292-298) concluded that four factors influenced the framing of terrorism post 9/11: culture, where events were 'manipulated to achieve a narrative or iconic victory'; government, 'through censorship and self censorship' that tended 'to prioritise elite or military interests'; real-world events; and public opinion, how frames shaped and reacted to public opinion. Strongest of these was elite or government sources, which acted as the primary definers, determining how events were constructed.

Studies of US journalism in the wake of 9/11 indicate that representations of terrorism can be understood through a conflict meta-frame, where two opposing perspectives were presented. In elite discourse this manifested itself in the rhetorical use of inclusive pronouns such as 'we' and 'us' (Kellner, 2002, 145). The news media also accepted without qualification the labelling of events and national security policy as a 'War on Terror' (Eisman, 2003; Glazier and Boydstun, 2012; Zelizer and Allan, 2002). Reese and Lewis (2009) argue that the reification and naturalisation of the War on Terror frame in the media meant that it became accepted to such an extent that it was used to describe general social conditions beyond terrorism and its associated policy issues. 
The conflict frame developed over time, with analyses indicating that agency shifted from the notion of (rogue) states or countries to a personification of the other, initially toward Osama bin-Laden, and then later American Muslim citizens (Karim, 2006). Terrorism-related episodes that challenged this narrative, such as violence perpetrated by US citizens, were often labelled differently, described as exceptional and isolated incidences. By associating Islam and Muslims with terrorism, this construction served to heighten unease or fear of Muslims as the other (Powell, 2011, 107).

Post 9/11 similar discourses of fear and negative portrayals of British Muslims were evident in the UK media. Nickels, Thomas, Hickman and Silvestri (2011) found that by articulating a distinction between moderate Muslims and radical Islamists, the national and regional press contributed to the construction of Muslim communities as 'a two-faced Janus, with the law abiding always defined in relation to extremists'. This narrative served to frame British Muslims as the constitutive other and the source of the threat posed by contemporary terrorism, placing the burden of challenging violent extremism squarely upon the shoulder of Muslim communities (Allen, 2004; Allen, 2007; Kassimeris and Jackson, 2012; McGhee, 2008).

The second broad assemblage prominent in UK news media representations of terrorism was a frame that drew on dominant security discourse, emphasising public preparedness and vigilance. (Hoskins and O'Loughlin, 2010; Jackson 2005; Richards 2007). Awan, Hoskins, and O'Loughlin (2011) examined television news coverage of two media events that are also analysed in the present study, the police raid in Forest Gate and transatlantic bomb plot in 2006. They found that news was characterised by 'uncertain and indefinite spatial boundaries', (82) and argue that this 'inadvertently sustained discourses of global fear and risk' (83).

Other studies have identified narratives that connect to or extend these two frameworks prominent in UK media portrayals of contemporary terrorism. A study of UK press discourse found, for example, that three predominant models of terrorism were prevalent in news coverage: an absolute model that 'offers an understanding of terrorism as an absolute force, which need not be analysed but which must be met with an equally absolute determination'; a reactive or retaliatory model, where terrorism is a 'response to perceived attacks on the Islamic world'; and an inevitability model which presents terrorism as an 'unstoppable force and destructive attacks are therefore inevitable' (Richards, 2007, 159, 160).

Papacharissi and Oliveira (2008) conducted a comparative frame analysis of media coverage of terrorism in quality US and UK newspapers. They found that the UK press tended toward more thematic coverage when reporting on terrorism or terrorism-related events, with a greater focus on the 'diplomatic evaluations' of terrorism (70). In both countries, the authors identified consistency between policy and media agendas. 
Significantly, the frames employed in terrorism coverage can intersect with public understanding of terrorism, 'including what people learn about any terrorist event, how they evaluate the main actors and issues under contention and how far this coverage affects public concerns and perceptions of the risks and threats of further terrorist acts' (Norris, Montague and Just 2003, 13).

Research has identified, for example, that coverage of particular incidents of political violence, such as the London bombings (Brinson and Stohl, 2009), and reporting on contemporary terrorism and its motivations which associated the threat with Islam, heighted public concern of the risk posed by terrorism (Woods, 2011) or influenced attitudes towards Muslims, increasing incidents of Islamaphobia (Ansari, 2006). Moreover, by embracing consensus or conflict frames in the aftermath of terrorist attacks such as 9/11 and the London bombings the news media contributed to enhanced support for governments and political leaders (Gadarian, 2010). Ultimately, these interpretative frameworks enhanced public support for particular policy responses (Jackson, 2005) or provided deliberative spaces that made certain outcomes, such as the implementation of legislation that infringed on civil liberties, seem more appropriate and acceptable (Spencer, 2010).

There are only a limited number of studies that have documented the nature of coverage and frames employed in news reporting on terrorism-related episodes. This study seeks to address this gap and examine the overall features of news discourse across a series of alleged plots that emerged as significant news events in the decade post 9/11.

Employing an inductive approach, the study sought to identify the frames and their characteristics across coverage of alleged plots, contrasting with studies that are deductive in nature, which seek to verify the presence of preexisting frames of terrorism.

The analytical focus of the study, however, on crisis-style episodes which were subsumed by politicians and the media alike into an overarching narrative to contemporary terrorism, also necessitated acknowledging the extent to which reporting on these events extended, or indeed challenged, the dominant media portrayals of terrorism outlined above, most significantly the securitisation discourse and an othering discourse of British Muslims and Islam. To this end the two empirical research questions that the study addressed were:

RQ1: What were the dominant frames employed in UK press coverage of alleged Islamist plots?

RQ2: How did news frames employed in coverage of alleged Islamist plots evolve across the period of analysis?

\section{Method:}


The study analysed news frames emerging across coverage of six key episodes occurring between 2001-11: ricin plot (January 2003); Old Trafford bomb plot (April 2004); Forest Gate raid (June 2006); transatlantic airliners plot (August 2006); kidnap plot (January 2007); and North West bomb plot (April, 2009).

Material was obtained from 11 national newspapers ${ }^{1}$ to reflect the varying characteristics of ownership, ideology and readership of the British press, using the News UK and LexisNexis databases. Articles were only drawn from the first three days of press coverage, since the focus of the study was to identify the dominant frames in process reporting on counter-terrorism operations connected to specific terrorist threats. Multiple search terms, including both generic, such as alleged plot and terrorism, and event-specific were used to produce a comprehensive sample of newspaper articles. Duplicate and irrelevant articles were identified and discarded after an initial sift. All articles were then read by the researchers to check their fit for inclusion in the sample, with only process, fact-based pieces reporting interventions by the police connected to an alleged terrorist plot included in the sample. Features, opinion, readers' letters and editorials were excluded due to the analytical focus of the study and because many pieces only made a passing reference to the police operation or alleged plot, thereby not fulfilling the criteria for inclusion in the sample.

This process yielded a total of 332 newspaper articles across the six episodes that formed the sample for analysis.

The study employed qualitative textual analysis to identify recurring themes and patterns present in the body of discourse (See Matthes, 2009). Developing an inductive approach, in line with recent studies of news frames of terrorism in US media coverage (Reese and Lewis, 2009; Powell, 2011), the textual analysis, sought to identify dominant news frames and their characteristics in British press reporting on alleged terrorist plots, and to then interpret the findings in the context of broader discourses on contemporary terrorism. Therefore, news texts were not analysed in isolation but were considered in relation to wider socio-political discourses (Fairclough, 1995).

One criticism of this interpretative approach to media frames is that 'there is a danger in this kind of lone-scholar analysis that the identification of a set of possible frames can be done arbitrarily' (Tankard, 2001, 97). Two separate coders, therefore, were used to reduce bias, with coders comparing notes on the separate textual elements and interpretations.

The analysis proceeded through four interrelating stages. First, researchers read through all news articles to ascertain common conceptual and thematic patterns (the macro components of a text [Van Dijk, 1988]), such as the central topic, narrative structure and recurring themes. As part of this process, for example, researchers noted whether themes were foregrounded (i.e. occurring in the headline or lead paragraph) within an article, or emerged as background reporting (positioned toward the end of an article). Second, 
researchers reread all news articles to identify the textual elements (micro components) that may reveal the presence of particular news frames. At this stage attention was paid to specific textual characteristics, with researchers highlighting common terms, words, metaphors, noting the use of particular language and tone, and the types of sources and their use. Third, researchers then met to compare notes and agree on a common set of frames that emerged from the textual analysis. In the final stage the textual elements of the frames were re-examined to consider their meaning in the context of broader sociopolitical discourses on terrorism, other key events that occurred during the decade post $9 / 11$ and existing research on media discourse on contemporary terrorism.

\section{Analysis of news framing of alleged Islamist plots}

This coding process revealed two dominant thematic frames were rendered in news media representations of alleged plots: an inevitability and preparedness frame, with alleged plots serving to remind or underline the risk posed by terrorism and a belonging frame, where alleged plots were portrayed as belonging to the Muslim communities disrupted by counter-terrorism operations. These two core thematic frames and their elements, as the findings reveal, often intertwined and the discussion below acknowledges the connections between these two interpretations.

\section{Inevitability and preparedness:}

Prior to the bombings and attempted bombings of July 2005, media representations of alleged Islamist plots were underlined by a discourse of a growing and inevitable threat from terrorism. This framing was predicated on a 'new terrorism' discourse, where a climate of fear and risk from terrorism became the dominant organising principle in the aftermath of the September 11 attacks (Mythen and Walklate, 2006).

A frame of inevitability was illuminated by narratives and headlines emphasising the timeliness and need for intervention by the police and security services. Headlines, stressed the dramatic elements of each episode, conveying the urgency and the immediacy of the situation. Newspaper accounts that described how counter-terrorism raids in North London in January 2003 had foiled a plot to disperse ricin poison in major population centres in the UK ran headlines expressing a tone of alarm and the proximity of attack. The Daily Mirror (January 8, 2003) described Britain 'On alert, with a similar theme suggested by a headline on the front page of the Independent newspaper (January 8, 2003), which claimed 'Alarm over terrorism suspects with deadly toxin'.

Beyond the headlines, the expression 'on alert' was common across popular press coverage of anti-terror raids connected to an alleged ricin plot, with the phrase prominent in articles from January 8, 2003 published in The 
Daily Mail, The Daily Express and The Daily Mirror. This construction, however, of the police operation as a crisis-intervention, necessary to disrupt a plot close to fruition, belied some of the key factual information presented in the news coverage. Many articles, for example, citing police and security sources, acknowledged that only 'traces' ("UK poison gas gang on loose", The Daily Express, January 8, 2003) or 'residues' of ricin had been uncovered during the initial searches by police ("Poison find sparks terror alert: Hunt for lethal toxin as six are held after raid on London flat." The Daily Telegraph, January 8, 2003; "Poison find sparks terror alert: Hunt for lethal toxin as six are held after raid on London flat." The Guardian, January 8, 2003).

Later episodes were presented through the same lens. Almost one year on from the London bombings of July 2005, a bungled police raid on a house in Forest Gate, East London in June 2006, which the news media linked to an imminent chemical bomb attack ("Fears of doomsday weapons." Sunday Express, June 4, 2006; "Police hunt lethal chemical suicide vest." The Times, June 3, 2006) was portrayed as another 'near miss', as indicated by the headlines that ran in The Times ("Police struck rapidly after chilling precise tip-off", 3 June, 2006) and The Sun ("We know a bomb's out there." June 3, 2006) newspapers. The motif of timeliness is clear from the description of police intervention provided by the Times but is also implied by the headline from the Sun, which is devoid of any expression of uncertainty. This is achieved by using a direct mode of address, thereby suggesting that information was gleaned from a source involved in the investigation or privy to security briefings, and by removing any modifiers that would indicate some level of doubt.

A theme of imminent threat was also discernible in the language used in articles reporting the Forest Gate raid, describing 'a deadly device...primed and ready to go' (The Sunday Express, June 4, 2006) and the search for evidence as a 'desperate search' for a chemical vest (The Times, June 3, 2006). This portrayal was challenged when subsequent information revealed that the search had failed to find any evidence of a chemical bomb. Despite the diminished threat, however, some reports claimed that the device may have been moved or hidden and that an attack was still possible ("Police fear bomb has been moved." The Daily Telegraph, June 5, 2006).

Looking further beyond July 2005, allegations that police had foiled a plot to kidnap and execute a Muslim soldier in the British army, was depicted in the British press as being 'at an advanced stage' ("Target Muslim squaddie." The Sun, February 1, 2007) and that the claims reflected an 'escalation' in a campaign of terrorism ("Terror suspects had 25 Muslims on hitlist." The Daily Express, February 2, 2007). Similarly, a series of anti-terror operations in north-west England in April 2009 were portrayed as demanding 'rapid and immediate' intervention by the police and security services. Illustrative of this construction were headlines in The Times (April 10, 2009) that described, 'A Countdown to a 
terror attack', and from the Daily Express (April 10, 2009), that proclaimed 'How we were just days from a terror disaster.'

Inevitability and preparedness were represented metaphorically through the rich imagery of time ticking away and a countdown to attack, positioning episodes as evidence that violent attacks or further attacks were a predictable consequence. As signifiers, they suggest greater insecurity, with each episode moving 'us' closer toward an inevitable outcome, as a plot is eventually brought to fruition.

Adjectives such as new, worrying and chilling were common across the six episodes, serving to distinguish the nature and scope of each threat from previous incidences of political violence. An alleged kidnap plot in early 2007, for example, was represented as a significant change in tactics, demonstrating that 'terrorism' had moved away from mass casualty attacks and the indiscriminate bombings of civilians to instead seeking to target individuals. Much of the press coverage contained elaborate details on how the plot had planned to replicate the kidnapping and beheading tactics employed by Iraqi insurgent groups, describing how the UK would see the 'horrors of Baghdad' or the Middle East brought to the streets of Birmingham ("From Baghdad to Birmingham? Nine held over plot to kidnap British Muslim soldier." The Independent, February 1, 2007; "A British beheading on the net." The Guardian, February 1, 2007)

The alleged plot, if confirmed, signals a new and worrying tactic by fanatical Islamic terrorists living in Europe ("Police battle to contain Muslim extremism." Financial Times, February 1, 2007).

Journalists, by describing foiled plots in weighty and ominous terms served to underline the risk from terrorism as a serious and ongoing concern, indicating a discourse of unease over future threats and focusing attention exclusively on the threat posed to the UK by Islamist groups. Such labels, also aided description and heightened the sense of crisis that were characteristic to media representations of alleged plots. At one level it could be argued, therefore, that such adjectives were used to convey the urgency with which intervention was required.

Highly speculative coverage typified press discourse on alleged plots but episodic frame components were more pronounced in the popular tabloid press. The contrast between broadsheet and tabloid newspaper coverage was most marked in reporting on a series of police raids in April 2004 that were connected to an alleged plot to target a public place in the city of Manchester. While across the ideological spectrum newspapers listed and discussed potential targets for the plot, tabloid publications made an explicit link between the raids and a plot to target Old Trafford with coordinated suicide bombings. Accounts from The Sun Newspaper, which ran with its infamous headline, 'Man U suicide bomb plot' (April 20, 2004), and the Daily Mail, were emotive and alarmist in equal measure. Broadsheet coverage, while still containing episodic frame-elements, gave more 
space to consider broader thematic frames, for example exploring the consistency of multiple suicide bombings with previous acts of violence perpetrated by militant Islamist groups.

Another framing device that served to underline the severity and risk that foiled plots represented was to draw on historical exemplars to illustrate their potential impact on individuals, infrastructure and society. Most common of which was to return to 9/11, with reporting on two episodes, the Old Trafford and transatlantic airliners plots, making comparisons between these alleged conspiracies and the 9/11 attacks. Similarly, in coverage of the ricin plot and Forest Gate raid, both associated with chemical threats, connections were made in news narratives between the plots and the sarin gas attack on the Tokyo Subway by Aum Shinrikyo in March 1995, with articles describing in some detail the methods and effects of the dispersal of poison in public areas ("Sarin used to deadly effect in Tokyo attack." The Sunday Telegraph, June 4, 2006). The potential consequences of using such examples are that they may invoke certain schema for audiences (Entman, 1993). Therefore by eliciting the collective memory of $9 / 11$ to narrate alleged plots it may have served to strongly equate present and future threats from terrorism with the September 11 attacks (Edy, 1999, 78).

The inevitability and preparedness frame was common across the body of discourse, researchers noted however that after the London bombings of July 2005 there was a subtle shift in the structuring of this frame, with the narrative arc of resilience becoming more prominent in coverage of later episodes. Reporting on an alleged plot to target transatlantic airliners in August 2006 and a counter-terrorism operation in 2009 emphasised how passengers or ordinary citizens were unconcerned by revelations. This narrative focus was in evidence in both broadsheet and tabloid coverage of the North West plot, describing how clubbers played on despite a "bomb plot" (The Times, 11 April 2009) and that shoppers were 'defying target scares' to enjoy an Easter 'spending spree in stores ("Shoppers defy target scares to enjoy Easter spree in stores." The Mirror, April, 11 2009; "Shopping on business as usual in Manchester." The Daily Telegraph, April, 11 2009). This theme was heightened when journalists employed a more interpretative style of reporting, evidenced by a piece published in The Times, which provided a lavish description of the entertainment at the Birdcage Nightclub, despite the venue being a target for the alleged North West plot (“Clubbers play on despite 'bomb plot." The Times, April 11, 2009).

The analysis also revealed that certain elements of the inevitability and preparedness frame were less perceptible in the Guardian newspaper, with researchers identifying a more critical and measured tone to reporting on the six episodes. In articles describing a foiled ricin plot, for example, the Guardian disputed, contrary to its presentation in other newspapers, that the men held in police custody were part of an al-Qaeda cell which sought to target the UK (Poison suspect trained at al-Qaida camp, The Guardian, January 10 th 2003). 
Furthermore, in coverage of the Old Trafford bomb plot, reports acknowledged speculation in other media outlets but refused to name potential targets ("Ten arrested as anti-terror police stage dawn raids", The Guardian, April 20 th 2004). In later episodes analysed in the study aspects of the Guardian's coverage also hinted at the presentation of a counter-frame, with space given to sources, including the police and legal representatives of arrested individuals, who were critical of the way elaborate details of alleged plots had been leaked to the media ("Police fear lurid terror briefings are being used to divert attention from Whitehall problems: Kidnap inquiry is hampered by speculation", The Guardian, February 3rd 2007).

\section{Belonging and responsibility frame:}

The second recurring frame identified in news discourse was for alleged plots to be portrayed as belonging to the predominantly Muslim communities in which counterterrorism operations took place.

This construction intertwined with and for later episodes to a large extent replaced the tendency for news media representations to fuse alleged plots with the issue of immigration and UK asylum policy (see Baker-Beall, 2013). Reporting on an alleged ricin plot in 2003 and the Old Trafford bomb plot in 2004 elaborated extensively on the immigration status of those arrested, labelling them as either 'recent migrants to the UK' or 'asylum seekers' ("Osama poison gang funded by DSS." The Sun, January 9, 2003).

Alleged plots were used, particularly within the tabloid and right-leaning press, to present a critique of immigration policy, drawing on negative portrayals of migrants. In the two episodes that occurred before 2005 the individuals arrested were described as 'fiddling income support' and 'lying to the DSS', despite any evidence of such being presented in the article. The Sun newspaper, for example, claimed that those arrested in connection with a ricin plot had entered the UK on forged passports but this information was provided without attribution to a source ("Osama poison gang funded by DSS." The Sun, January 9, 2003). In contrast, matters of criminal process and specific details of the alleged conspiracies were supported through references to police or unnamed security sources.

When reporting moved towards additional analysis and context, the political and social issue of immigration was foregrounded. Articles, for example, précised statistics on immigration and applications for asylum in the summary lead before making a connection to the specific security threat, as illustrated below.

Thousands of teenage asylum seekers are living alone under little or no supervision it emerged last night. The shock figures came to light following revelations that two of the ricin terror suspects are 17-year old refugees ("Thousands of teenage asylum seekers left to their own devices." Daily Mail, January 10, 2003). 
Supporting this representation, articles reflected concerns about government provision for refugees and asylum seekers by seeking to explain 'how immigration rules forced' local councils to support the individuals arrested ("Council paid for flat used as terror laboratory." The Times, January 9, 2003). Earlier episodes analysed in the study, therefore, reproduced a discourse that equated the contemporary terrorist threat with immigration and asylum policies.

The youths, now being questioned by police, were classed under national immigration rules as unaccompanied minors and were cared for out of public funds by Islington council social services department ("Council paid for flat used as terror laboratory." The Times, January 9, 2003).

The actions of arrested individuals and exposés of alleged terrorist conspiracies were therefore attributed to the failure of government immigration and asylum policy.

The analysis indicates that the belonging and responsibility frame became more prominent after July 2005. Two elements of this belonging frame were a shift to a more contextual reporting style, offering analysis or perspectives that went beyond the 'who-what-when-where' of a recent event (Fink and Schudson, 2014,11 ) and constructing narratives through the personal reflections and voxpops of local residents. Both broadsheet and tabloid newspapers' reporting on an alleged kidnap plot, for instance, were infused with rich description of the areas and communities in the West Midlands where police raids had taken place. The summary lead below from a piece in The Times is illustrative of this trend.

It is hard to find anyone in this quiet suburb who does not believe arrests are a con-trick
to demonise Muslims To wander the streets of Sparkbrook yesterday, from shabby
corner shop to proud, white-domed mosque, was to enter a world where conspiracy
theories are the breath of life ("Plots and paranoia are mainstream views for Muslims of
Sparkbrook", The Times, February 2, 2007).

Articles also assessed the implications of counterterrorism operations on the UK's Muslim communities, presenting the personal testimony of local residents, who expressed both surprise that those arrested were suspected of terrorism offences and anxiety about the potential repercussions of allegations for public perception of their community.

"This is having a very damaging effect on our society," said Mr Hussein. "We came here to work hard and bring our children up as good British citizens. What has gone wrong? "What is happening to our families when you challenge your son: where are you going; what are you looking at on the internet; what are you talking to your friends about? All it does is cause divisions ("To the sound of splintering doors, police squads storm homes of suspects." The Daily Telegraph, February 1,2007). 
Other articles focused almost exclusively on local residents' perspectives on the impact of police raids on their community, social cohesion and the reliability of evidence that precipitated anti-terrorism operations ("Politics, propaganda, and persecution: how Muslims see the raids." The Independent, February 2, 2007; "Plots and paranoia are mainstream views for Muslims of Sparkbrook." The Times, February 2, 2007).

Community and religious leaders also featured prominently as sources, and were quoted appealing for calm and encouraging restraint ("Keep Calm; Fear of Muslim backlash increases after police raids." The Daily Mirror, February 3, 2007) but also challenged the government's handling of terrorism, accusing the government of inventing the terror threat ("Muslim unrest as terror police carry out new raids." The Daily Telegraph, February 3, 2007).

\footnotetext{
Sheikh Mohammed bal Qadri, deputy director of the Islamic Academy said: "There are no suspicious activities at this mosque. Since September 11 we have been very vigilant, as mosques should be. If I see a person who is new, I ask him why he is here and what he is doing. We are against those evil acts ("Terror arrests after fears of football bomb The Times." April 20, 2004).
}

One possible consequence of constructing narratives to alleged plots from the perspectives of the Muslim communities affected by police operations is that it portrays these episodes, and by association the wider threat from contemporary terrorism, as belonging to these communities. As other research has shown, giving local residents a right of reply to allegations of terrorism and anti-Muslim sentiment simultaneously reflected and recycled a discourse that 'challenged and questioned the loyalty of young Muslims to their countries' (Marranci, 2006, 100) and contributed to the representation of Muslim communities as 'suspect' (Pantazis and Pemberton, 2009; Nickels, Thomas, Hickman and Silvestri, 2011). Therefore, by identifying individuals from Muslim communities as the focus for counter-terrorism operations, it may serve to reinforce a negative representation of Muslim communities and Islam through its association with terrorism and extremism (Awan, Hoskins, and O'Loughlin, 2011, 79).

With information about foiled terrorist plots more often attributed to unnamed police sources (Matthews, 2013), some have argued, therefore, that in the absence of official (on the record) information journalists turned to local people when reporting such breaking news events (Awan, Hoskins, and O'Loughlin, 2011, 67). The foregrounding of Muslims' perspectives in press coverage however, also indicates the presence of broader discourses of contemporary terrorism, specifically, the Blair government's counter-terrorism strategy, which placed the burden of responsibility on the UK's Muslim communities for challenging extremism and radicalisation. This 'partnership approach' was contradictory since it defined Muslim communities as suspect but 
required the support of this community to counter radicalisation and extremism (McGhee, 2008, 52). So giving British Muslims space to express their opinion on events and challenge negative perceptions of their communities may be indicative of the emergence of a counterframe in reporting on alleged plots. Ultimately, however, this frame failed, and instead only provided a vivid illustration of community tension and Muslim hostility toward an antagonistic counter-terrorism strategy (Flood, Hutchings, Maiazhevich and Nickels, 2012, 251).

Drawing on the reflections of friends and neighbours may also have perpetuated an exclusionary discourse. The analysis indicates that individuals arrested in connection with alleged plots were positioned as marginalised members of their community due to their increasing religiosity. Press coverage of the 2006 Forest Gate raid, for example, was illustrative of this trend, with neighbours describing how the two brothers arrested 'underwent a transformation after the September 11 attack on America' ("MI5 fears silent army of 1,200 biding its time in the suburbs in the wake of terror raid." The Sunday Telegraph, June 4, 2006), becoming more religious ("Terror raid: Men in gas masks, a broken window, then a single shot: Bleeding man seen leaving house after 250 officers stage dawn raid following two month surveillance operation." The Guardian, June 3, 2006). The evidence that is presented, however, for this increasing religiosity is simply attributed to their background or supported by describing how those arrested had adopted Islamic religious practices, such as wearing traditional clothing and adopting beards ("One guy came out. They gave him some gas and took him away." The Independent, June 3 , 2006).

Other suspects arrested in connection with alleged plots were conversely referred to as 'ordinary', illustrated by descriptions of their place of work, in schools and shops, or social activities, especially those that have a cultural resonance with notions of Britishness. This is exemplified by a piece from the Daily Mirror, where one of the suspects arrested in connection with a plot to kidnap a serving British solider is described as 'Terry the Terminator' due to his prowess with a cricket bat, and as a dedicated family man "who didn't ram Islam down your throat" ("The Terminator." The Daily Mirror, February 3, 2007). This portrayal, while less perceptible than the rendering of suspects increased religiosity, may have still served to reinforce differences between Muslims and non-Muslims, as such representations position Muslim culture and diversity in relation perceived British values and institutions which are purported to embody and express these values. (Kalra and Kapoor, 2009).

\section{Further discussion and conclusions}

News accounts of counter-terrorism operations linked to alleged plots were more often rendered through episodic frames, focusing on matters of criminal process, the nature of specific threats and public reaction to these episodes. The 
analysis, however, revealed that these event-orientated narratives reflected discourses on contemporary terrorism, with two thematic frames prominent: an inevitability and preparedness frame and a belonging and responsibility frame.

Alleged plots were presented as evidence that 'terrorist' violence or further violence was inevitable by emphasising elements that underscored the severity and risk posed by each episode. This was despite only two of the six plots analysed in the study being subsequently verified as credible threats, with 18 people eventually convicted of terrorism-related offences in connection with the transatlantic airliners and kidnap plots, (CPS, 2008; CPS, 2010). For the other episodes analysed in the study, all arrested individuals were eventually released without charge or convicted of lesser offences unrelated to terrorism. Contrary to their presentation in the initial press coverage, allegations of a ricin plot in 2003, sensationalist reports of a foiled plot to target Old Trafford in 2004, a counterterrorism raid in Forest Gate in 2006 that was linked to a chemical bomb threat, and a series of arrests in north-west England in 2009, were never substantiated. Media coverage of alleged plots, however, seldom reflected on the outcome of previous high-profile police raids and as new episodes emerged across the period of study they were reconstituted as part of the broader discursive framework of contemporary terrorism.

The analysis also revealed that after the bombings and attempted bombings in London in July 2005, alleged plots were framed as belonging to the Muslim communities disrupted by police operations, replacing a discourse of immigration and asylum that was discernible in earlier episodes analysed in the study. This belonging frame was communicated by journalists drawing on the perspectives of the local communities, including the family and friends of arrested individuals.

Giving voice to those communities affected by counter-terrorism operations is indicative or broader discourses on contemporary terrorism, with Muslim communities positioned in relation to extremists (Nickels, Thomas, Hickman and Silvestri, 2011), reflecting the UK government's post 9/11 counterterrorism strategy, particularly the PREVENT strand of CONTEST 1 introduced under Blair's premiership ${ }^{2}$ that emphasised the role of Muslim communities in responding to the challenges of radicalisation and extremism (Home Office, 2006; McGhee, 2008, 79).

From the analysis, there are three areas that require further elucidation. First, the findings from this study illustrate the congruence's between elite and policy frames and press framing of terrorism (Brinson and Stohl, 2009; Papacharissi and Oliveira, 2008). Earlier episodes rearticulated government discourse, with alleged plots serving to underline the risk of future terrorist violence. Journalism therefore operated within the discursive boundaries established by the Blair government's counter-terrorism strategy, which presented terrorism as a pervasive and yet unknowable risk (Awan, Hoskins, and O'Loughlin, 2011, 6). As the Blair government strategy moved toward 
understanding and addressing the antecedents of radicalisation of young Muslims, greater attention was paid to the role of Britain's Muslim communities in 'preventing terrorism' (McGhee, 2008, 79). Press coverage of alleged plots mirrored this policy shift, with frame elements contributing to the presentation of alleged plots as belonging to the Muslim communities affected by counterterrorism operations. Specifically, drawing on the experiences and perspectives of local residents and family, friends and neighbours of individuals arrested reflected discourses of community cohesion.

Second, as studies of US journalism in the years after 9/11 have also shown, the analysis indicates that the British press adopted a consensus frame (Schudson, 2002) when reporting on terrorism-related episodes, accepting rather countering government-sponsored frames on contemporary terrorism. One possible consequence of journalists presenting a framework of interpretation that emphasised invulnerability and preparedness and equated terrorism with a particular minority group within British society is that these become 'persistent patterns of cognition and interpretation' (Gitlin, 1980, 7), which are then used to lend a narrative coherence to other connected events and policy spheres. Over time, these structures can make certain policy outcomes seem more acceptable (Entman, 1993). In the UK, the political construction of terrorism was used to legitimise a raft of policy measures introduced in the decade post $9 / 11$, and in particular by the Blair government, that were deemed necessary to maintain security and combat terrorism (Jackson, 2005). Therefore by presenting alleged plots through a frame of inevitability of violence or further violence by radical Islamists it reinforced the appropriateness of government counter-terrorism strategies that seek to address potential invulnerabilities. Similarly, presenting alleged plots as belonging to the UK's Muslim communities and accordingly positioning these communities as responsible for addressing the problem by rooting out radical extremists, may have made policy that unduly targets individuals from these communities, intruding on civil liberties and the rights of individuals, seem legitimate and proportional.

Third, the study also shows that in the immediate coverage of terrorismrelated episodes, where news reporting often focuses on describing the events and capturing reactions, dominant discourses on contemporary terrorism were still prominent. This is despite having less space to pull back from the story and consider events within the context of wider issues and trends. Given the significance and fluidity of the issue over the period of study, extending the analysis to commentary and editorial pieces would have undoubtedly revealed some of the discourses on terrorism and counter-terrorism policy. The purpose, however, of this study was to consider speculative, and at the time of reporting unproven threats, to examine how these were presented to news audiences.

Through a longitudinal study of a series of events occurring across the decade post 9/11 which were subsumed into an overarching narrative to contemporary terrorism, the central argument put forth in this paper is that it 
was not only the attention that was paid to these terrorism-related episodes that was significant but how their representation intersected with national and political discourses on terrorism. Further study into media framing of other national or local terrorism-related episodes, and their constitution as part of broader frameworks of meaning, will contribute to our understanding of the role of the media in the social construction of terrorism.

\section{Acknowledgements}

I would like to thank Ashley Crowson for his assistance in analysing the data and also the anonymous reviewers for their helpful comments and suggestions.

\section{Notes}

1. The Daily Mail/Mail on Sunday; The Sun/The News of the World; The Daily Mirror/the Sunday Mirror; The Times/The Sunday Times; The Independent/The Independent on Sunday; The Daily Telegraph/The Sunday Telegraph; The Guardian/The Observer; The Daily Express/The Sunday Express; The Daily Star; The Sunday People and The Financial Times

2. Subsequently revised in July 2009 and July 2011

\section{References}

Allen, C., 2004. Justifying Islamophobia: A post-9/11 consideration of the European Union and British contexts. The American Journal of Islamic Social Sciences, 21(3), 1-25

Allen, C., 2007. Islamaphobia and its consequences. In European Islam challenges for public policy and society, edited by A. B. Samir Amghar and Michael Emerson, 144-167. Brussels: Centre for European Policy Studies. .

Allen, C., 2010. Islamophobia. Farnham: Ashgate.

Ansari, F., 2006. British anti-terrorism: a modern day witch-hunt. Wembley: Islamic Human Rights Commission.

Archetti, C., 2013. Understanding terrorism in the age of global media: a communication approach. New York, Palgrave Macmillan.

Awan, A. N., Hoskins, A., and O'Loughlin, B., 2011. Radicalisation and the media: connectivity and terrorism in the new media ecology. London: Routledge.

Baker-Beall, C., 2013. The evolution of the European Union's 'fight against terrorism' discourse: Constructing the terrorist 'Other'. Cooperation and Conflict, 5(2), 188-206

Brinson, M., and Stohl, M., 2009. From 7/7 to 8/10: Media framing of terrorist incidents in the United States and United Kingdom. In The faces of terrorism: multidisciplinary perspectives, edited by David Canter, 227-244. Oxford: Wiley-Blackwell.

Burkitt, I. , 2005. Powerful emotions: Power, government and opposition in the 'War on Terror'. Sociology: the Journal of the British Sociological Association, 39(4), 679-695. 
Carruthers, S., 2000. The media at war: communication and conflict in the $20^{\text {th }}$ century. Basingstoke: Palgrave Macmillan

Cobain, I., Dodd, V., and Woodward, W., 2007. Terror leaks: Both Home Office and police implicated. The Guardian, 26 April. Available at: http://www.guardian.co.uk/politics/2007/apr/26/uk.terrorism (accessed 1 June 2012).

Crenshaw, M., 1981. The Causes of Terrorism. Comparative Politics, 13(4), 379399.

Crown Prosecution Service, 2008 Five men sentenced over terrorism offences connected to the Birmingham beheading plot. Available at: http://www.cps.gov.uk/news/press_releases/107_08/ (accessed 20 September 2009)

Crown Prosecution Service, 2010 Three men linked to liquid bomb plot guilty of conspiracy to murder. Available at: http://www.cps.gov.uk/news/press_releases/125_10/index.html (accessed 20 September 2009).

De Vreese, C., 2005. News framing: theory and typology, Information Design Journal and Document Design, 13(1), 51-62.

Edy, J. A., 1999. Journalistic uses of collective memory. Journal of Communication, 49(2), 71-85.

Eisman, A., 2003. The media of manipulation: patriotism and propaganda mainstream news in the United States in the weeks following September 11. Critical Quarterly, 45(1), 55-72.

Entman, R., 1993. Framing: toward clarification of a fractured paradigm. Journal of Communication, 43(4), 51-58.

Fairclough, N., 1995. Media discourse. London: Edward Arnold

Fink, Katherine, and Schudson, Michael., 2014. The Rise of Contextual Journalism, 1950s-2000s. Journalism: Theory, Practice, and Criticism 15(1), 3-20

Flood, C., Hutchings, S., Maiazhevich, G., and Nickels, H. C., 2012. Islam, security and television news. Basingstoke: Palgrave Macmillan.

Gadarian, S. K., 2010. The politics of threat: How terrorism news shapes foreign policy attitudes. The Journal of Politics, 72(2), 469-483

Gamson, W. A., and Modigliani, A., 1989. Media discourse and public opinion on nuclear power: A constructionist approach. American Journal of Sociology, 95(1), 1-37

Gitlin, T., 1980. The whole world is watching: Mass media in the making \& unmaking of the new left. Berkeley: University of California Press

Glazier, R. A. and Boydstun, A. E., 2012. The President, the press, and the war: A tale of two framing agendas. Political Communication, 29(4), 428-446.

Graber, D. A., 1997. Mass media and American politics. Washington, D.C.: CQ Press. 
Hall, S., 1973. Encoding and decoding in television discourse, University of Birmingham: Centre for Contemporary Cultural Studies.

Home Office., 2006. Countering International Terrorism: The United Kingdom's Strategy. London: TSO. Available at:

https://www.gov.uk/government/uploads/system/uploads/attachment_ data/file/272320/6888.pdf (accessed on 26.1.15)

Hoskins, A., and O'Loughlin, B., 2010. War and media: the emergence of diffused war. Cambridge, UK: Polity Press.

Iyengar, S., and Kinder, D. R., 1987. News that matters: Television and American opinion. London: University of Chicago Press.

Jackson, R., 2005. Writing the war on terrorism: Language, politics and counterterrorism. Manchester: Manchester University Press.

Karim, H.K., 2006 American media coverage of Muslims: the historical roots of contemporary portrayals. In Muslims and the News Media, edited by E. Poole and J. Richardson, 116-127. London: IB Tauris.

Kalra, V.S. and Kapoor, N., 2009. Interrogating segregation, integration and the community cohesion agenda. Journal of Ethnic and Migration Studies, 35 (9), 1397-1415.

Kassimeris, G. and Jackson, L., 2012. British Muslims and the discourses of dysfunction: community cohesion and counterterrorism in the West Midlands. Critical Studies on Terrorism, 5(2), 179-196.

Kellner, D., 2002. September 11, the media, and war fever. Television \& New Media, 3(2), 143-151.

Lewis, J., 2012. Terrorism and news narratives. In Media and terrorism: global perspectives, edited by D. Freedman and D. K. Thussu, 77-94. London: SAGE.

Marranci, G., 2006. Jihad beyond Islam. Oxford: Berg.

Matthes, J., 2009. "What's in a Frame? A Content Analysis of Media Framing Studies in the World's Leading Communication Journals, 1990-2005." Journalism \& Mass Communication Quarterly, 86(2): 349-367.

Matthews, J., 2013. News narratives of terrorism: Assessing source diversity and source use in UK news coverage of alleged Islamist plots. Media, War \& Conflict, 6(3), 295-310.

McGhee, D., 2008. The end of multiculturalism?: terrorism, integration and human rights. Maidenhead: Open University Press.

Midlarsky, M., Crenshaw, M. and Yoshida, F., 1980, Why violence spreads: the contagion of international terrorism, International Studies Quarterly, 24(2), 262-298

Miller, D. and Sabir, R., 2012. Propaganda and terrorism in Media and terrorism: global perspectives, edited by D. Freedman and D. K. Thussu, 77-94. London: SAGE.

Mythen, G. and Walklate, S., 2006. Communicating the terrorist risk: harnessing a culture of fear? Crime Media Culture, 2(2), 123-142. 
Nickels, H. C., Thomas, L., Hickman, M. J. and Silvestri, S., 2011. De/constructing 'Suspect Communities' Journalism Studies, 13(3), 340-355.

Norris, P., Montague, K. and Just, M. (Eds.). 2003. Framing Terrorism. New York: Taylor and Francis Group.

Pan, Z. and Kosicki , G.M., 1993. Framing analysis: An approach to news discourse. Political Communication 10(1), 55-75.

Pantazis, C. and Pemberton, S., 2009. From the 'Old' to the 'New' suspect community: examining the impacts of recent counter-terrorist legislation. British Journal of Criminology 49(5), 646-666

Papacharissi, Z., and Oliveira, M., 2008 News frames terrorism: A comparative analysis of frames employed in terrorism coverage in US and UK newspapers, The International Journal of Press/Politics 13(1), 52-74

Perse, E. M., 2001. Media effects and society. Mahwah, New Jersey: Lawrence Erlbaum Associates.

Picard, R. G., 1991. The journalist's role in coverage of terrorist events. In Media coverage of terrorism: Methods of diffusion, edited by O. A. Alai and K. K. Eke, 40-62. London: Sage.

Poole, E., and Richardson, J. E., 2006. Muslims and the news media. London: I. B. Tauris.

Powell, K. A., 2011. Framing Islam: An analysis of U.S. media coverage of terrorism since 9/11. Communication Studies, 62(1), 90-112

Reese, S.D. and Lewis., S. C., 2009 Framing the War on Terror: The internalization of policy in the US press. Journalism, 10 (6), 777-797

Richards, B., 2007 Emotional governance: Politics, media and terror. Basingstoke: Palgrave Macmillan.

Scheufele, D. A., 1999. "Framing as a theory of media effects." Journal of Communication, 49(1): 103-122.

Schudson, M., 2002. What's unusual about covering politics as usual. In Journalism after September 11, edited by B. Zelizer and S. Allan, 44-54. London: Routledge.

Spencer, A., 2010. The tabloid terrorist: the predicative construction of new terrorism in the media. Basingstoke: Palgrave Macmillan.

Tankard, J. W., 2001. The empirical approach to the study of media framing. In Framing public life: Perspectives on media and our understanding of the social world, edited by Oscar Gandy, Stephen Reese, and August Grant, 96105. Mahwah, N.J: Lawrence Erlbaum

Van Dijk, T. A., 1988 News as discourse. London: Lawrence Erlbaum Associates.

Van Gorp, B., 2007. The constructionist approach to framing: Bringing culture back in. Journal of Communication, 57(1), 60-78.

Wilkinson, P., 1997. The media and terrorism: a reassessment. Terrorism and Political Violence, 9(2), 51-64.

Woods, J. , 2011. Framing terror: an experimental framing effects study of the perceived threat of terrorism. Critical Studies on Terrorism, 4(2), 199-217. 
Xigen, L., \& Izard, R., 2003. 9/11 Attack coverage reveals similarities, differences. Newspaper Research Journal, 24(1), 204-219.

Zelizer, B., and Allan, S., 2002. Journalism after September 11. London: Routledge. 